\title{
The Armenian nuclear power plant: problems of electricity export
}

\author{
Vahe Davtyan ${ }^{1, *}$ \\ ${ }^{1}$ Yerevan Brusov State University of Languages and Social Sciences, 375002, Toumanyan str., 42, \\ Yerevan, Armenia
}

\begin{abstract}
The prerequisites for the development of Armenia's nuclear power industry are indicated. The main geopolitical problems of operation of the Armenian NPP are revealed through studying the electric power market of the South Caucasus with the definition of the export opportunities of Armenia. The main problems of nuclear fuel supplies to the Armenian NPP are studied. Recommendations are given on the longterm development of nuclear energy in Armenia.
\end{abstract}

\section{The frameworks of nuclear policy}

Beginning from the mid-20th century, nuclear power is one of the key and at the same time ambiguously evaluated branches of world energy, which is due to its direct influence on international relations and geopolitical processes. The essence of "atomic geopolitics" can be briefly described the following way: the presence of developing nuclear energy in a country indicates its energy self-sufficiency and a high level of energy security, while its absence or gradual freezing is a characteristic of countries with a low level of "energy sovereignty" that depends from external supplies of energy resources and electricity. (This applies also to countries with a developed energy system that chose to conserve nuclear power plants, for example, Germany, which refused nuclear power after the accident at the Fukushima-1 NPP in 2011, followed by a sharp increase in consumption of traditional energy resources - gas and coal, which also determines the desire to continue a stable cooperation with the Russian "Gazprom" - the main supplier of natural gas to Germany). Along with this, the availability of nuclear energy also indicates the export capabilities of the country, while the export of energy resources or electricity is an important prerequisite for the geopolitical positioning of the state. Moreover, the presence of an atomic complex increases the strategic importance of the country and creates additional security mechanisms in the presence of external threats. Thus, in terms of the level of development of the nuclear power industry, states can conditionally be divided into three main groups:

1. "nuclear protectionism" (or absolutism);

2. "nuclear liberalism"

3. "nuclear discrimination" [1].

In the first group, we are dealing with countries in which nuclear power is a priority, and for its development the state takes all the necessary legislative, political, financial, and

\footnotetext{
* Corresponding author: vahedavtyan@yandex.ru
} 
economic measures. Protectionism is also manifested in the fact that the state does not allow private capital (especially foreign) into the nuclear sector, treating it as a zone of state strategic interests. Moreover, the state controls not only the operation of nuclear power plants and the supply of electricity, but also the production of the equipment for the operation of the stations. This is mainly due to security considerations. In the states of this group, special taxation is often applied to the industry, or taxes are not applied at all. Russia and China can be included in the group of nuclear protectionists' countries. In these countries, not only the production of the necessary equipment, but also the process of NPP construction is carried out by companies with a predominant share of state capital.

The second, liberal group includes countries in which almost identical conditions are created for the development of all spheres of energy. The role of the state in the industry is limited only to the control function mainly in matters related to security: certification, monitoring, licensing, etc. The development of the industry depends on objective conditions, and the main actor here is private capital, which excludes the formation of a state monopoly. However, this does not at all mean that the state remains on the sidelines of nuclear energy. The only specificity is that within the framework of this model of development of nuclear energy the state is inferior to the private sector in terms of participation (including financial). The nuclear industry is open to foreign investment, which is often fixed at the legislative level. As for equipment, there is also competition between foreign and domestic suppliers. This group includes, above all, the United States, as well as Canada, Finland, and others.

The third group includes countries that openly impede the development of the nuclear industry for a number of reasons. Most of those reasons are reduced to environmental ones. However, corporate interests of companies involved in hydrocarbon energy and, in fact, forming an international anti-nuclear lobby should not be excluded. The main feature of this group is not only the lack of state support, but also the creation of discriminatory conditions for the functioning of the industry. This is manifested in the additional taxation of companies operating nuclear power plants, the artificial creation of an unfavorable investment climate in the industry, the support of hydrocarbon or renewable energy, etc. This group includes countries such as Germany, Switzerland, Belgium, Taiwan, Austria, and others. It should be noted that not only countries, but also certain international political institutions, can be the 'nuclear discrimination' policy makers. On 6 July 2017, the European Parliament passed a resolution with a majority of votes calling on Turkey to abandon the construction of the Akkuyu NPP due to seismic safety. The project is carried out within the framework of the intergovernmental agreement between Russia and Turkey in 2010, wherein, 51 percent of 'Akkuyu Nuclear' JSC belong to Russian companies. Although the resolution has a recommendatory character, it nevertheless reflects the mood of certain political elites of the EU, both in relation to Russian energy policy and to nuclear energy in general.

It should be taken into account that none of the presented models are absolute for a single country, and often the boundary between them is very vague, which is explained by the change in the economic and geo-economic situation. For example, China, with a predominantly protectionist model, is actively looking for foreign markets to supply Chinese-made equipment, while the US (during Trump's presidency), a falling into the liberal category, currently does not hide its skepticism about the export of American nuclear (and energy in general) technologies. There are also countries that are actively developing nuclear power, applying the basic principles of both a protectionist and a liberal model. An example is India, which created favorable conditions for the implementation and further operation of its main nuclear project - Kudankulam NPP, in parallel with this, inviting foreign companies ('Rosatom' from Russia) to participate in the construction of the facility. 
In Armenia, which fits mostly in a protectionist model, nuclear power is proclaimed a state monopoly. Today, the nuclear power plant is not only one of the main electricity producers in the country, but also an important guarantor of its energy independence and energy security. According to the Law on Energy of RA (Chapter 2, Article 6), "nuclear power is a state monopoly. The state bodies authorized by the Government of the Republic of Armenia control the activities of forming the organizational, legal and technical systems of nuclear and radiation safety. The issues of nuclear energy, its impact on the environment and security are regulated in accordance with international treaties and the legislation of the Republic of Armenia" [2].

According to the "Energy Security Concept of the Republic of Armenia", energy security is a complex of political, economic, legal, organizational, methodological and other measures that ensures high-quality and reliable energy supply at economically reasonable prices to meet the state's needs on an everyday basis, as well as in emergency situations and during the war [3]. When addressing the main risks and threats that could potentially impede the full functioning of the country's energy security system, the Concept focuses on the exploitation of the Armenian NPP. In particular, the emergence of obstacles in the process of building a new nuclear block instead of acting is considered as a key threat capable of violating the logic of the republic's energy development.

The Armenian nuclear power plant, as a guarantor of Armenia's energy security, is considered as one of the leading factors for increasing the economic and, as a result, political competitiveness of Armenia in the region. Under the Soviet regime, the RA energy system was designed as an energy surplus, covering part of the region's needs, as a result of which Armenia today is able to ensure uninterrupted export of electricity to neighboring countries. Obviously, if there is a power deficit in countries such as Georgia, Azerbaijan, Turkey, Iran and Iraq, the Republic of Armenia has every chance to declare itself as a key player in the regional electric power market, which is especially actual in the context of exclusion of Armenia from a number of transport and energy (mainly pipeline) projects in the region.

During the Soviet period, Armenia was the leader among the electricity producers of Transcaucasia. Since the mid-1970s, it has become its permanent exporter to neighboring countries, which was largely due to the launch of the Armenian NPP. Today, the Armenian NPP faces a set of problems, the main of which are reduced to the search for funds for the construction of a new unit and the development of an optimal scenario for the future of the Armenian nuclear energy. In this context, Armenia's interaction with the key geopolitical actors of the region and, in particular, with Russia, and the formation of effective methods of participation in diplomatic and media battles initiated with regard to the operation of the Armenian nuclear power plant mainly by Turkey and Azerbaijan, are becoming increasingly important. To identify the main geopolitical problems of the operation of the Armenian NPP, let us turn to the historical prerequisites for its construction.

\section{Armenian NPP and the problems of electricity export}

The development of nuclear energy and technology is directly related to geopolitical factors. According to N. de Blasio and R. Nephew, nuclear energy can play a constructive role in covering energy needs in the 21 st century in both developed and emerging markets. At the same time, for a fully-fledged and safe development of the industry, it is necessary to purposefully support state institutions that stimulate and coordinate the investment activity of the private sector [4].

The export component, in fact, has a great importance in this context, as the future of the Armenian NPP is largely determined by the export activity [5]. In this sense, the search for electricity sales markets in the region is a strategic task for Armenia, which, in general, 
also corresponds to the philosophy of the European Energy Charter, the country is a member of [6].

As a guarantor of Armenia's energy security, the Armenian NPP is also considered as one of the leading factors for increasing the economic and, as a result, geopolitical competitiveness of Armenia in the region. The lack of own hydrocarbon reserves, dependence on supplied energy resources, the blockade of railway and pipeline communications, limited electricity export opportunities and geopolitical tensions in the region dictate the need to find funds for the construction of a new unit of the Armenian NPP capable of bringing Armenia to a new level of energy independence. As already mentioned, under the Soviet regime, the Armenian energy system was designed as an energy surplus, covering part of the region's needs, as a result of which Armenia today is able to ensure uninterrupted export of electricity to neighboring countries. Obviously, if there is a shortage of electricity in the countries of the region, the Republic of Armenia has every chance to declare itself as a key player in the regional electric power market. Taking into account the possible annual electricity production volumes, the forecasts for electricity necessary for Armenia's domestic consumption, as well as the capacity of inter-system transmission lines with neighboring countries, the total volumes of electricity supplied from the Armenian energy system to the energy systems of Georgia, Turkey and the Islamic Republic of Iran (which will become possible while ensuring the joint operation of the energy systems of these countries) may amount to approximately 6 billion $\mathrm{kW} / \mathrm{h}$ per year [7].

However, a number of geopolitical factors, such as closed borders, the absence of diplomatic and, therefore, economic ties with two neighboring states, the unsettledness of the Karabakh conflict, etc., hamper the full-fledged positioning of Armenia in the corresponding context. It should also be understood that the protracted process of solving the above-mentioned problems negatively affects the full-fledged use of export potential, which was built up in the USSR.

Turning to the prospects of export in the Georgian direction, it should be noted that in 2000-2007 about $15 \%$ of the consumed electricity was exported from Armenia to this country with current energy consumption of 8.5 billion $\mathrm{kWh}$. Now this indicator decreases from year to year. Georgian authorities are currently pursuing an active policy aimed at liberalizing the energy market, as well as international positioning of Georgia as a low-cost electricity exporting country, which became particularly relevant in with the launch of the Azerbaijan-Georgia-Turkey energy bridge capable of exporting electricity to Turkey up to $700 \mathrm{MW}$. Export of electricity from Armenia to Georgia is carried out only on a seasonal basis, as well as during accidents in the Georgian energy system.

As for Turkey, for the period of 1995-2007 the demand for electricity had been increasing by $6.6 \%$ per year. In 2015-2016 years the increase was $8.5 \%$. It is expected that the electricity consumption in Turkey, which reached its peak level of 170 billion $\mathrm{kW} . \mathrm{h}$ in 2006, will increase approximately threefold to 2020, reaching 499 billion $\mathrm{kW}$. h. To ensure this level of consumption in Turkey, it is necessary to triple the installed capacity of power plants: from 38,500 to $96,000 \mathrm{MW}$ in 2020 [7].

Currently, the export of Armenian electricity to the Turkish market is directly linked to the opening of the Armenian-Turkish border. The protracted process of ratification of the Zurich protocols (and later thir suspension) had a definite effect on a number of accords of a purely economic character that existed between Armenia and Turkey after September 2008, when Turkish President Abdullah Gul had an official visit to Yerevan. Within the framework of the meeting, the issue of electricity export from Armenia to Turkey was discussed. Initially, it was assumed that Armenia would begin direct electricity supplies to Turkey in the spring of 2009. A corresponding agreement was concluded during the visit of the Turkish President to Armenia between the Ministry of Energy and Natural Resources of 
Armenia, CJSC "High Voltage Electric Networks" and the Belgian company "UNIT" engaged in import and distribution high voltage electricity in Turkey. Currently, Turkey is actively developing its own capacities, and is also implementing a project to build a nuclear power plant "Akkuyu" with a capacity of $4800 \mathrm{MW}$ [8]. Today, along with the construction of the Turkish Stream gas pipeline, the "Akkuyu" nuclear power plant is the locomotive of Russian-Turkish economic relations. Along with this, the construction of the "Akkuyu" NPP is carried out under very favorable conditions for Turkey. For example, there are no obligations of the Turkish side for the construction of power lines and substations; it is not entirely clear whether there will be demand for electricity generated at nuclear power plants, since the latter is located near Antalya resort, which does not have large industrial enterprises; the price of electricity is fixed for 25 years without taking into account the inflation of the dollar and the growth of world prices for electricity; in the agreement there is no article on force majeure circumstances, and there is also no ban on the nationalization of the nuclear power plant. All these aspects, identified by the Institute of Energy Problems (RF), ultimately make the project not entirely appropriate for Russia $[9,11]$. Nevertheless, "Akkuyu" repeated the fate of the Turkish Stream: after the shot down of the Russian SU24 fighter, the future of the nuclear power plant was in question, but already in August 2016, Presidents Putin and Erdogan agreed to resume the project, and in May 2017 the official Kremlin announced the investment of $\$ 22$ billion in the construction of nuclear power plant $[10,12]$.

As for Iran, there is a lack of 2,500 MW in energy capacity and it is growing from year to year. However, the Iranian authorities are also consistent in solving problems related to energy supply to the population and the economy, as evidenced by the construction of the nuclear power plant in Bushehr with the participation of Russia. At the same time, the energy security of the Islamic Republic (especially its northern provinces) is partly attributed to the supply of $3.2 \mathrm{kWh}$ of electricity from Armenia, instead of 1 cubic meter of natural gas supplied via the Iran-Armenia gas pipeline, according to the barter formula. It should be noted that the energy dialogue between Armenia and Iran can be particularly active in connection with the lifting of sanctions against the Islamic Republic, which, first of all, should be reflected in the implementation of the project of the Meghri hydro power plant.

At the same time, we should take into account the fact that the implementation of the North-South electricity corridor could significantly change the situation in the future. As we know, in April 2016 the energy ministers of Russia, Armenia and Iran signed a road map for the energy corridor. Within the framework of the program, , the construction of electricity transmission lines between Armenia and Iran with the financing of the Iranian side, as well as the construction of a high-voltage transmission line between Armenia and Georgia for KfW bank loans. The construction of 400-kilovolt power lines Iran-Armenia and Armenia-Georgia will allow expanding communication between the energy systems of the countries. Today, the power grids of Iran and Armenia, as well as Georgia and Russia operate in synchronous mode. The signing of the agreement will allow the energy networks of all four countries to work in synchronous mode with a capacity of overflows of up to 1200 MW [13].

Here we can make a conclusion that the breakthrough of the energy blockade is the main challenge for the Armenian economy. In this regard, it is necessary not only to pursue an active policy aimed at building new infrastructures, but also to apply market mechanisms to ensure a low cost of electricity produced. In particular, the talk is about lowering the cost of electricity produced in Armenia, which will allow it to be more competitive in foreign markets, while currently generated electricity in the Armenian energy system is inferior in its pricing of electricity produced by Georgian hydroelectric power plants. It is obvious that with the continuation of the tendency to increase the cost of 
production, Armenian electricity will be less attractive for the Georgian market. At the same time, it is important to note that the formation of such a trend, on the one hand, is due to the limited sales market, on the other hand, it is directly related to multimillion-dollar loans that are periodically attracted to the Armenian energy system, affecting tariff formation. This issue should also be considered in the context of Armenia's integration into the common electric power market of the Eurasian Economic Union (EEU) with the possibility of delivering along the "North-South" corridor to Russia and further to Kazakhstan and Kyrgyzstan - countries with a power deficit.

\section{Conclusion}

French geopolitician Jacques Attali proposes to consider economic development as the basis of civilizational development in general. Based on this thesis, he suggests replacing the notion of "geopolitics" with "geo-economics", which, in his opinion, better reflects the essence of world politics. In fact, this is a concept that reduces the civilizational process not to geography, culture or religion, but directly to the economic reality. According to Attali, it is the economic power and the possibility of its spread that shapes the civilizational image of the state / region and determines its place in the world. In this sense, along with the development of financial institutions, the build-up of productive power and trade is viewed as the basis for the geo-economic advancement of the state [14]. It is obvious that the continuous development of such a strategic production direction as nuclear power, as well as the establishment of stable export communications can significantly enhance the international status of Armenia and create serious guarantors of national security.

The presence of an atomic complex increases the strategic importance of the country and creates additional security mechanisms in the presence of external threats, which also determines the geopolitical significance of the Armenian nuclear power plant. Lack of own hydrocarbon reserves, dependence on supplied energy resources, blockade of railway and pipeline communications, limited electricity export opportunities and geopolitical tensions in the region dictate the necessity of finding funds for the construction of a new unit of the Armenian NPP.

As a guarantor of Armenia's energy security, the Armenian NPP should be considered as one of the leading factors for increasing the economic and, as a result, political competitiveness of Armenia in the region. Under the Soviet regime, the Armenian power system was designed as an energy surplus, covering part of the region's needs, as a result of which Armenia today has capacities capable of ensuring the uninterrupted export of electricity to neighbouring countries. This issue should also be considered in the context of Armenia's integration into the common electric power market of the Eurasian Economic Union with the possibility of deliveries along the North-South corridor to Russia and to other member countries. Armenia needs to declare itself as a key player in the regional electric power market, which is especially important in connection with the exclusion of the country from a number of transport and energy (mainly pipeline) projects at the regional level. Such positioning is impossible without the development of nuclear energy, traditionally considered as the basis of Armenia's energy policy.

\section{References}

1. T. E. Doyle, Ethics and Global Politics, 6, 3 (2013)

2. Republic of Armenia, Law on Energy of the Republic of Armenia, 2001.03.22 / 10 (142) (2001) 
3. Government of the Republic of Armenia, The concept of ensuring the energy security of the Republic of Armenia: Decision N50 of December 22, 2011 (2011)

4. N. de Blasio and R. Nephew, The geopolitics of nuclear power and technology (Columbia University, New York, 2017)

5. N. Ghvinadze and L. Linderman, Cross-border electricity exchanges: bolstering economic growth in the South Caucasus and Turkey (Atlantic Council, Washington, 2013)

6. A. Aslanidze, The role of the energy charter in promoting electricity cooperation in the South Caucasus (Energy Charter Secretariat Knowledge Center, Brussels, 2016)

7. K. Karapetyan, 21st Century: Information and Analytical Journal, 2, 10 (2009)

8. A. Telli, Caucasus International, 6, 2 (2016)

9. All risks of the Akkuyu project (http://www.proatom.ru/modules.php?name= News\&file $=$ article\&sid $=3715,2016$ )

10. Putin called the amount of investment in the construction of the Turkish nuclear power plant Akkuyu (https://ria.ru/atomtec/20170503/1493600158.html, 2016)

11. A. V. Bogoviz, S. V. Lobova, Y. V. Ragulina, A. N. Alekseev, International Journal of Energy Economics and Policy, 8(3), 67-75 (2018)

12. A. V. Bogoviz, S. V. Lobova, Y. V. Ragulina, A. N. Alekseev, International Journal of Energy Economics and Policy, 7(5), 93-101 (2017)

13. Armenia, Russia, Georgia and Iran signed the "road map" of the energy corridor "North-South" (http://newsarmenia.am/news/armenia/armeniya-rf-gruziya-i-iranpodpisali-dorozhnuyu-kartu-energokoridora-sever-yug, 2017)

14. J. Attali, A brief history of the future (Arcade Publishing, New York, 2011) 